\title{
Land Use Effects on Soil Quality Indicators: A Case Study of Abo-Wonsho Southern Ethiopia
}

\author{
Awdenegest Moges, ${ }^{1}$ Melku Dagnachew, ${ }^{2}$ and Fantaw Yimer ${ }^{3}$ \\ ${ }^{1}$ School of Biosystems and Environmental Engineering, Hawassa University, P.O. Box 5, Hawassa, Ethiopia \\ ${ }^{2}$ Department of Natural Resources Management, Wolaita Sodo University, P.O. Box 138, Wolaita Sodo, Ethiopia \\ ${ }^{3}$ Wondo Genet College of Forestry and Natural Resources, Hawassa University, P.O. Box 128, Shashemene, Ethiopia
}

Correspondence should be addressed to Awdenegest Moges; awde_moges@yahoo.co.uk

Received 5 March 2013; Revised 29 April 2013; Accepted 10 May 2013

Academic Editor: Artemi Cerda

Copyright (C) 2013 Awdenegest Moges et al. This is an open access article distributed under the Creative Commons Attribution License, which permits unrestricted use, distribution, and reproduction in any medium, provided the original work is properly cited.

Soil quality assessment is valuable for evaluating agroecosystem sustainability, soil degradation, and identifying sustainable land management practices. This study compared soil quality within culturally protected forest areas and adjacent grassland, grazing land, and farmland in Abo-Wonsho, Southern Ethiopia. A total of 40 soil samples ( 4 land uses $\times 5$ replications $\times 2$ soil depth layers: 0 to $10 \mathrm{~cm}$ and 10 to $20 \mathrm{~cm}$ ) were collected for analysis. Soil textural fractions (i.e., sand, silt, and clay percentage) varied with land use and soil depths even though the textural class across all land use types was sandy loam. Bulk density, soil organic carbon (SOC), and available potassium (K) varied significantly: $P=0.041, P=0.001$, and $P<0.001$, respectively, with land use and soil depth, but other indicators showed no significant difference. We conclude soil quality can be protected and maintained by improving existing land use practices within both agricultural and modern forest management areas.

\section{Introduction}

Soil quality can be defined as "the capacity of a specific kind of soil to function within natural or managed ecosystem boundaries to sustain plant and animal productivity, maintain or enhance water and air quality, and support human health and habitation" [1]. It is usually considered to have three main aspects reflecting physical, chemical, and biological soil properties and is important for assessment of land degradation and for identification of sustainable land use practices [2,3]. The main consequences of inappropriate land use changes are land degradation and soil quality deterioration through loss of vegetative cover, top soil moisture, infiltration capacity, water storage, soil organic matter, fertility, resilience, natural regeneration capacity, and a lower water table, factors that are critical for soil health [4]. Recent reports on land use and land management effects on soil quality have been documented particularly in relation to soil degradation and restoration in north west Thailand [5], visitors activities and management on the surface soil [6] and effect of long term cultivation [7] in Turkey, and the influence of agricultural management systems on soil biological quality in Spain [8]. Land use and management are influencing not only soil properties but also soil erosion processes. While unsuitable agricultural practices can cause soil erosion, on the contrary use of cover can reduce risk of erosion $[9,10]$.

There is also a growing interest in understanding and integrating local knowledge into natural resource management studies [11]. Local Indigenous Knowledge (IK) is defined as tacit knowledge of a community, that is either generated locally or imported and transformed before being incorporated into the day-to-day life of a community [12]. Information refined and transferred across successive generations produces an understanding of natural resources and relevant ecological processes [13].

In Ethiopia, IK has been shown to be of paramount importance for sustainable natural resource management 
activities including soil and water conservation in Konso [14], irrigation practices in Tigray [15], and stone bund in North Shoa [16], reporting that forests around churches [17] are the most protected in northern Ethiopia where people consider the place to be a most holy place.

Likewise, culturally protected areas such as the AboWonsho are also common in the Sidama Zone of Southern Ethiopia. Abo-Wonsho is Sidama's cultural heritage and exemplary natural protection endeavor that has been protected as a sacred place by the Sidama people for the last several decades. It is traditionally believed that the area has been under protection for at least 21 generations (oral communication with cultural leaders from Abo-Wonsho). However, very little is known about this cultural practice with regard to improving or protecting soil quality, its benefits, or its constraints for sustained use of natural resources. The extent and rate of soil quality change in relation to culturally protected forest area with the adjacent land use types were not identified and quantified. Moreover, there has been no documented evidence on how and why such systems are maintained for longer time periods. Therefore, understanding the soils' physical and chemical qualities and variability is of paramount importance for utilization and site-specific management practices of soil resources $[18,19]$. The general objective of this study was to assess soil quality for culturally protected forest areas and adjacent agricultural areas. The specific objectives were to quantify and compare changes in soil physical and chemical quality indicators and to evaluate effects of land use changes on the variability of selected soil properties.

\section{Materials and Methods}

2.1. Description of Study Site. Abo-Wonsho is located in the outskirt of Bokasso town which is the capital of Wonsho district in Sidama Zone, Ethiopia. It is about $12 \mathrm{~km}$ to the east of Yirgalem town (Figure 1) and $329 \mathrm{~km}$ south of Addis Ababa. Geographically, it is located at $06^{\circ} 45^{\prime} 11^{\prime \prime} \mathrm{N}$ and $38^{\circ} 30^{\prime} 16^{\prime \prime} \mathrm{E}$ with an altitude ranging from $1978 \mathrm{~m}$ (West, lower end) to $2149 \mathrm{~m}$ (East or upper end) above sea level.

2.1.1. Climate, Geology, and Soil. The study area has a mean annual rainfall and temperature ranging from $832 \mathrm{~mm}$ to $1658 \mathrm{~mm}$ and $18-21^{\circ} \mathrm{C}$, respectively. The pattern of rainfall distribution is bimodal. The short rainy season lasts from mid November to February whereas the long rainy season is during summer and it extends up to October [20]. According to [21], the Wonsho district can be divided in to four local climatic zones, on the basis of altitudinal and annual rainfall variations, as "Wet Dega," "Moist Woyna Dega," "Wet Woyna Dega," and "Wet Kola". Accordingly, the study site is observed to be "Wet-Woyna Dega" (Wet mid-highland). Geologically, the Precambrian rock with ages of over 600 million years forms the foundation of basement complex rocks. The Wonsho district also contains a wide variety of sedimentary, volcanic, and intrusive igneous rocks which have been metamorphosed to varying degrees containing the metallic deposits [21].
2.1.2. Farming System and Land Use. In the study area, agriculture is characterized by subsistence mixed crop-livestock farming. Most of the area around the homestead is covered with perennial Enset (Ensete ventricosum), which is a staple food and income source. Coffee (mainly Coffee arabica) and Chat (Catha edulis), and fruit trees such as papaya (Carica papaya), banana (Musa species), avocado (Persea americana) and mango (Mangifera indica) are also among the widely cultivated crops. Vegetables such as potato, cabbages, onion, carrot, pumpkins, and green pepper are grown intercropped either with Enset or coffee. Annual crops such as maize, sorghum, barley, wheat, bean, pea, and haricot bean are most commonly cultivated. The description of each land use type is presented as follow.

Protected Forest Land. It is composed of various indigenous trees, shrubs, and bushes like Podocarpus falcatus (Zigba), Strychnos spinosa (Dokma), Croton macrostachyus (Bisana), Arundinaria alpine (Mountain bamboo), Pouteria adolfifriedericii (or Aningeria adolfi-friedericii, Keraro), Juniperus procera (Tid), Cordia africana (Wanza), Prunus Africana (Tikur-enchet), Euphorbia candelabrum (Kulkual) Millettia ferruginea (Birbira), and Vernonia amygdalina (Grawa). In the forest, farmers have the right to use the forest for their livestock grazing. However, the culture has not allowed replanting (reforestation) and the newly germinating seedlings have been destroyed by animals browsing and trampling.

Open Grassland. It is predominantly of very short grasses and situated within the protected area. This land use system is denuded of trees, shrubs, and bushes and open for grazing. It is also believed to be created due to the shrinkage of the forest cover as a result of deforestation due to human and animal interference.

Farmland. It is characterized by cultivation of crops. The main cropping system is mixed cropping system where a combination of trees, shrubs, and perennial crops such as coffee, Enset, and chat are grown together as an agroforestry system. Farmers usually use live fence of various tree species around and in their farmland for shade, firewood, and fodder and soil fertility improvement. Some of the tree species that farmers are usually used to grow for soil fertility improvement are Cordia africana (Wanza), Croton macrostachyus (Bisana), Millettia ferruginea (Birbira), and Vernonia amygdalina (Grawa).

Grazing Land. It is used as grazing for cattle and is considered as communal grazing land. It is adjacent to the protected forest area and owned by a group of farmers in which other farmers who do not belong to this group have no right to use. The main difference between the open grassland and grazing land is that open grassland is free for every one to use for grazing, while grazing land is restricted to a certain group of farmers.

2.2. Soil Sampling and Analysis. Soil samples were collected from the four main land use types described above (protected forest land, open grassland within the culturally protected 


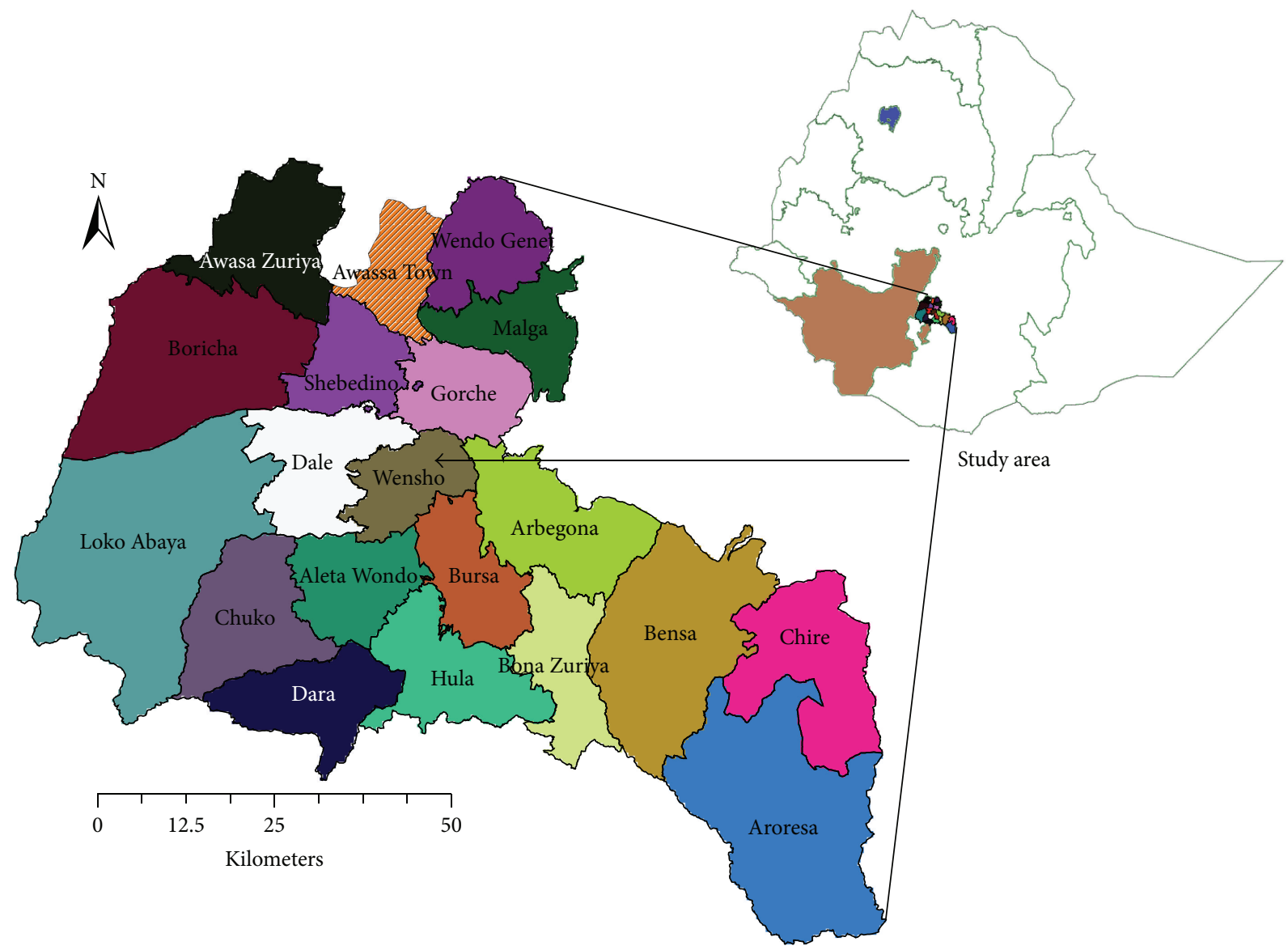

Figure 1: Map of the study area.

area, communal grazing land, and farmlands). Soil samples were taken from two depths: 0 to $10 \mathrm{~cm}$ and 10 to $20 \mathrm{~cm}$. Sample plots had dimensions of $20 \times 20 \mathrm{~m}\left(400 \mathrm{~m}^{2}\right)$ with an "X" design and samples taken from the four corners and center of each sample plot and pooled. Approximately one kilogram of composite sample from each soil depth was taken and put into plastic bags, air-dried at room temperature, crushed, homogenized, and passed through a $2 \mathrm{~mm}$ sieve before laboratory analysis. A total of 40 soil samples (four land use types $\times$ five replicates of sample plots $\times$ two soil depth classes: 0 to 10 and 10 to $20 \mathrm{~cm}$ ) were collected for soil analysis. Undisturbed samples were taken with a core sampler that was $10 \mathrm{~cm}$ long and $7.2 \mathrm{~cm}$ in diameter for bulk density determination.

Most soil analyses were undertaken at the National Soil Laboratory and Research Center, Addis Ababa, following standard procedures and methods as described below. Bulk density was determined by the core method [22] at Wondo Genet College of Forestry and Natural Resources' soil laboratory. Soil textural fractions were analyzed following the hydrometric method after removing organic matter using $\mathrm{H}_{2} \mathrm{O}_{2}$ and thereafter, dispersing the soils with sodium hexameta-phosphate [23]. The USDA particle size classes, namely, sand $(2.0-0.05 \mathrm{~mm})$, silt $(0.05-0.002 \mathrm{~mm})$, and clay $(<0.002 \mathrm{~mm})$, were used to classify the textural classes. Soil organic carbon (SOC) was determined by the WalkleyBlack oxidation method [24]. Total nitrogen (TN) was determined using the Kjeldahl distillation method [25], and available phosphorous (AP) was determined using Olsen's extraction method (UV/visible Spectrometer, Lambda EZ 201) [26]. Available potassium (Av. K) was determined by Sodium Acetate method [27]; the exchangeable bases $\left(\mathrm{Ca}^{2+}\right.$, $\mathrm{Mg}^{2+}, \mathrm{K}^{+}$and $\mathrm{Na}^{+}$) were measured by atomic absorption spectrophotometry (NOV AA 400) after extraction with ammonium acetate at $\mathrm{pH} 7$ [23]. The cation exchange capacity (CEC) was determined by extraction with ammonium acetate [28]; soil $\mathrm{pH}$ was determined by potentiometric methods using 1:2.5 soil: water ratio. Percent base saturation (PBS) was calculated by dividing the sum of the charge equivalents of the base cations $\left(\mathrm{Ca}^{2+}, \mathrm{Mg}^{2+}, \mathrm{K}^{+}\right.$, and $\left.\mathrm{Na}^{+}\right)$by the CEC of the soil and multiplying by 100 .

2.3. Statistical Analysis. Land use types and soil depth were used as independent variables (factors) and the soil parameters as dependent variables. The significance difference of soil quality indicators with land use types and soil depth was tested using analysis of variance (ANOVA) following the general linear model (GLM) procedure at $(P \leq 0.05)$. Tukey's honest significance difference (HSD) test was used for mean 
TABLE 1: Soil textural fractions $\left(\mathrm{gKg}^{-1}\right)$, and soil bulk density $\left(\mathrm{BD}, \mathrm{Kgm}^{-3}\right)$ in relation to land use (Mean \pm S.E. $)$ and soil depths $(\mathrm{cm})$.

\begin{tabular}{|c|c|c|c|c|c|c|}
\hline \multirow{2}{*}{ Variables } & \multirow{2}{*}{ Depth $(\mathrm{cm})$} & \multicolumn{4}{|c|}{ Land use types } & \multirow{2}{*}{ Overall } \\
\hline & & Protected forest & Open grassland & Farmland & Grazing land & \\
\hline \multirow{3}{*}{ Sand } & $0-10$ & $784.0( \pm 13.6)$ & $714.0( \pm 15.0)$ & $604.0( \pm 17.2)$ & $686.0( \pm 9.8)$ & $697.0( \pm 8.2)^{b}$ \\
\hline & $10-20$ & $710.0( \pm 20.7)$ & $69.00( \pm 18.9)$ & $632.0( \pm 16.0)$ & $624.0( \pm 18.1)$ & $66.40( \pm 8.2)^{\mathrm{a}}$ \\
\hline & Overall & $74.70( \pm 11.7)^{\mathrm{c}}$ & $70.20( \pm 12.1)^{b}$ & $618.0( \pm 12.0)^{\mathrm{a}}$ & $655.0( \pm 14.2)^{\mathrm{a}}$ & \\
\hline \multirow{3}{*}{ Silt } & $0-10$ & $172.0( \pm 18.3)$ & $172.0( \pm 16.6)$ & $250.0( \pm 12.6)$ & $214.0( \pm 6.8)$ & $202.0( \pm 8.5)^{\mathrm{a}}$ \\
\hline & $10-20$ & $178.0( \pm 20.8)$ & $190.0( \pm 15.8)$ & $194.0( \pm 24.6)$ & $244.0( \pm 14.0)$ & $201.5( \pm 8.5)^{\mathrm{a}}$ \\
\hline & Overall & $175.0( \pm 13.1)^{\mathrm{a}}$ & $181.0( \pm 11.2)^{\mathrm{ab}}$ & $222.0( \pm 16.0)^{b c}$ & $229.0( \pm 8.9)^{\mathrm{C}}$ & \\
\hline \multirow{3}{*}{ Clay } & $0-10$ & $44.0( \pm 7.5)$ & $114.0( \pm 29.1)$ & $146.0( \pm 7.5)$ & $100.0( \pm 8.9)$ & $101.0( \pm 6.6)^{\mathrm{a}}$ \\
\hline & $10-20$ & $112.0( \pm 10.2)$ & $120.0( \pm 7.1)$ & $174.0( \pm 9.8)$ & $132.0( \pm 11.1)$ & $134.5( \pm 6.6)^{b}$ \\
\hline & Overall & $78.0( \pm 12.8)^{\mathrm{a}}$ & $117.0( \pm 14.1)^{\mathrm{b}}$ & $160.0( \pm 7.5)^{\mathrm{C}}$ & $116.0( \pm 8.6)^{\mathrm{b}}$ & \\
\hline \multirow{3}{*}{$\mathrm{Bd}$} & $0-10$ & $960( \pm 30)$ & $1010( \pm 60)$ & $910( \pm 40)$ & $970( \pm 10)$ & $960( \pm 30)^{\mathrm{a}}$ \\
\hline & $10-20$ & $1030( \pm 30)$ & $1070( \pm 110)$ & $1030( \pm 30)$ & $1010( \pm 20)$ & $1040( \pm 30)^{\mathrm{b}}$ \\
\hline & Overall & $1000( \pm 20)^{\mathrm{a}}$ & $1040( \pm 60)^{\mathrm{a}}$ & $970( \pm 30)^{\mathrm{a}}$ & $990( \pm 10)^{\mathrm{a}}$ & \\
\hline
\end{tabular}

Overall means within rows and columns followed by different letters are significantly different $(P<0.05)$ with land use and soil depths.

separation when the analysis of variance showed statistically significant differences $(P<0.05)$.

\section{Results and Discussions}

\subsection{Soil Physical Properties}

3.1.1. Soil Textural Fractions $\left(g \mathrm{Kg}^{-1}\right)$. The results of soil physical properties are presented in Table 1 . The soil textural fractions of sand, silt, and clay significantly varied with land use types, while sand and clay varied with soil depth and the interaction effect was significant for sand fraction (Table 2). The overall sand, silt, and clay fractions were, respectively, higher in soil under the protected forest followed by the open grazing lands than in other land use types (Table 2). In the studied soil, clay fraction was less than $200 \mathrm{gkg}^{-1}$ across all land use types and soil depths. With respect to land use types, however, the mean clay fraction was relatively higher $\left(160 \mathrm{gkg}^{-1}\right)$ under farmland and the least in the protected forest land $\left(78 \mathrm{gkg}^{-1}\right.$, Table 1$)$ and was also higher in the 10$20 \mathrm{~cm}$ soil layers across all land use types.

The higher clay fraction in soil under farmland than other land use types might be due to the fact that cultivation promotes further weathering processes as it shears and pulverizes the soil and changes the moisture and temperature regimes [29]. The higher clay fraction in subsurface layer than in the top surface soil may indicate possible clay translocation from the top layer to the layer below $[30,31]$. The increase in clay fraction with increasing depth and the lowest overall mean proportion of clay fraction compared to the sand and silt fractions concurs with the results of other studies $[18,32]$. Moreover, the textural class across all land use types is sandy loam, indicating the homogeneity of soil forming processes and similarity of parent materials [33]. However, over a very long period of time, pedogenesis processes such as erosion, deposition, eluviations, and weathering can change the soil texture $[33,34]$.
3.1.2. Bulk Density $\left(\mathrm{Kgm}^{-3}\right)$. In the study area, the overall mean soil bulk density did not show any significant difference with respect to land use types $(P=0.565)$ and the interaction effects $(P=0.091$, Table 2$)$, Soil bulk density under different land use types generally ranges from 970 (in the farmland) to $1040 \mathrm{Kgm}^{-3}$ (in the open grassland). Similar studies (e.g., [35]) also reported that land use types and their interactions did not affect the soil bulk density. However, other studies $[32,36,37]$ found that bulk density significantly varied with land use types due to differences in the land management and land use histories.

Difference in soil bulk density with soil depth was significant $\left(P=0.041\right.$, Table 2), higher in the lower $\left(1040 \mathrm{Kgm}^{-3}\right)$ than in the top surface soil layer $\left(960 \mathrm{Kgm}^{-3}\right)$, indicating the tendency of bulk density to increase with depth due to the effects of weight of the overlying soil and the corresponding decrease in soil organic matter content [34]. The relatively lower bulk density in the top surface than in the lower layer may reflect organic matter concentration.

\subsection{Soil Chemical Properties}

3.2.1. Soil Organic Carbon Content (SOC, $g \mathrm{Kg}^{-1}$ ). The overall soil organic carbon content showed significant variation with land use types $(P=0.001)$, soil depths $(P<0.001)$ and their interaction effect $(P<0.001$, Table 4$)$. The overall SOC content was higher under protected forest $\left(29.7 \mathrm{gKg}^{-1}\right)$ and grazing land $\left(26.0 \mathrm{gKg}^{-1}\right)$ than in the farmland $\left(18.4 \mathrm{gKg}^{-1}\right.$, Table 3). Across all land uses SOC content was significantly higher in the top surface than in the lower layer. In the top surface SOC content was significantly higher under protected forest land $\left(41.8 \mathrm{gKg}^{-1}\right)$ followed by the grazing land than in other land use types (Table 3). In the lower soil layer, SOC content did not show any significant differences across all land use types $(P>0.05$, Table 3$)$. The lower SOC content under farmland than in grazing land and protected forest could be due to the reduced amount of organic material 
TABLE 2: Summary of two-way ANOVA for soil textural fractions and bulk density relation to land use and soil depths.

\begin{tabular}{lccccccccc}
\hline \multirow{2}{*}{ Sources of variations } & \multirow{2}{*}{ Df } & \multicolumn{2}{c}{ Sand } & \multicolumn{2}{c}{ Silt } & \multicolumn{2}{c}{ Clay } & Bd \\
& & MS & $P$ & MS & $P$ & MS & $P$ & MS \\
\hline Land use (LU) & 3 & 314.7 & $<0.001$ & 76.63 & 0.004 & 112.3 & $<0.001$ & 0.008 \\
Depth $(D)$ & 1 & 108.9 & 0.008 & 0.025 & 0.967 & 112.23 & 0.001 & 0.055 & 0.041 \\
LU $* D$ & 3 & 52.70 & 0.018 & 36.63 & 0.073 & 16.49 & 0.155 & 0.002 & 0.910 \\
Error & 32 & 13.59 & & 14.38 & & 8.825 & & 0.012 \\
\hline
\end{tabular}

TABle 3: SOC $\left(\mathrm{gKg}^{-1}\right), \mathrm{TN}\left(\mathrm{gKg}^{-1}\right), \mathrm{C} / \mathrm{N}$ ratio, $\mathrm{pH}\left(\mathrm{H}_{2} \mathrm{O}\right), \mathrm{Av} \cdot \mathrm{P}\left(\mathrm{mgKg}^{-1}\right)$, and Av. $\mathrm{K}^{+}(\mathrm{cmol}(+) / \mathrm{kg}$ soil $)$ in relation to land use and soil depth $(\mathrm{cm})($ Mean \pm S.E) .

\begin{tabular}{|c|c|c|c|c|c|c|}
\hline \multirow{2}{*}{ Variables } & \multirow{2}{*}{ Depth $(\mathrm{cm})$} & \multicolumn{4}{|c|}{ Land use types } & \multirow{2}{*}{ Overall } \\
\hline & & Protected forest & Open grassland & Farmland & Grazing land & \\
\hline \multirow{3}{*}{ SOC } & $0-10$ & $41.8( \pm 3.6)$ & $25.1( \pm 1.8)$ & $19.8( \pm 1.7)$ & $30.2( \pm 0.20)$ & $29.2( \pm 1.3)^{b}$ \\
\hline & $10-20$ & $17.6( \pm 2.1)$ & $23.0( \pm 3.8)$ & $17.0( \pm 1.9)$ & $21.7( \pm 0.23)$ & $19.8( \pm 1.3)^{\mathrm{a}}$ \\
\hline & Overall & $29.7( \pm 4.5)^{\mathrm{a}}$ & $24.1( \pm 2.0)^{\mathrm{ab}}$ & $18.4( \pm 1.3)^{\mathrm{a}}$ & $26.0( \pm 0.20)^{\mathrm{b}}$ & \\
\hline \multirow{3}{*}{$\mathrm{TN}$} & $0-10$ & $2.6( \pm 0.8)$ & $1.4( \pm 0.6)$ & $1.4( \pm 0.2)$ & $2.5( \pm 0.04)$ & $1.7( \pm 0.3)^{\mathrm{a}}$ \\
\hline & $10-20$ & $1.6( \pm 0.8)$ & $1.4( \pm 0.5)$ & $1.3( \pm 0.5)$ & $1.8( \pm 0.04)$ & $1.5( \pm 0.3)^{\mathrm{a}}$ \\
\hline & Overall & $2.1( \pm 0.6)^{\mathrm{a}}$ & $1.4( \pm 0.4)^{\mathrm{a}}$ & $1.4( \pm 0.2)^{\mathrm{a}}$ & $2.1( \pm 0.03)^{\mathrm{a}}$ & \\
\hline \multirow{3}{*}{$\mathrm{C}: \mathrm{N}$} & $0-10$ & $47.85( \pm 14.45)$ & $53.68( \pm 31.04)$ & $15.42( \pm 3.43)$ & $14.87( \pm 4.44)$ & $32.96( \pm 6.85)^{\mathrm{a}}$ \\
\hline & $10-20$ & $11.46( \pm 4.01)$ & $29.84( \pm 11.37)$ & $26.40( \pm 12.21)$ & $13.51( \pm 2.04)$ & $20.30( \pm 6.85)^{\mathrm{a}}$ \\
\hline & Overall & $29.66( \pm 9.31)^{\mathrm{a}}$ & $41.76( \pm 16.08)^{\mathrm{a}}$ & $20.91( \pm 6.25)^{\mathrm{a}}$ & $14.19( \pm 2.31)^{\mathrm{a}}$ & \\
\hline \multirow{3}{*}{$\mathrm{pH}$} & $0-10$ & $5.97( \pm 0.14)$ & $5.34( \pm 0.31)$ & $6.15( \pm 0.21)$ & $5.67( \pm 0.10)$ & $5.78( \pm 0.11)^{\mathrm{a}}$ \\
\hline & $10-20$ & $5.44( \pm 0.23)$ & $5.40( \pm 0.28)$ & $5.70( \pm 0.23)$ & $5.67( \pm 0.05)$ & $5.55( \pm 0.11)^{\mathrm{a}}$ \\
\hline & Overall & $5.70( \pm 0.16)$ & $5.37( \pm 0.20)^{\mathrm{a}}$ & $5.92( \pm 0.16)^{\mathrm{a}}$ & $5.67( \pm 0.05)^{\mathrm{a}}$ & \\
\hline \multirow{3}{*}{ Av. P } & $0-10$ & $1460( \pm 260)$ & $1130( \pm 430)$ & $5120( \pm 1020)$ & $2140(890)$ & $2460( \pm 590)^{\mathrm{a}}$ \\
\hline & $10-20$ & $3790( \pm 1710)$ & $2090( \pm 620)$ & $3940( \pm 2280)$ & $2250( \pm 620)$ & $3020( \pm 590)^{\mathrm{a}}$ \\
\hline & Overall & $2630( \pm 900)^{\mathrm{a}}$ & $1610( \pm 390)^{\mathrm{a}}$ & $4530( \pm 1190)^{\mathrm{a}}$ & $2190( \pm 510)^{\mathrm{a}}$ & \\
\hline \multirow{3}{*}{ Av. $K^{+}$} & $0-10$ & $0.28( \pm 0.03)$ & $0.12( \pm 0.01)$ & $0.29( \pm 0.04)$ & $0.13( \pm 0.01)$ & $0.21( \pm 0.02)^{\mathrm{a}}$ \\
\hline & $10-20$ & $0.23( \pm 0.08)$ & $0.11( \pm 0.01)$ & $0.18( \pm 0.03)$ & $0.10( \pm 0.01)$ & $0.16( \pm 0.02)^{\mathrm{a}}$ \\
\hline & Overall & $0.26( \pm 0.04)^{\mathrm{b}}$ & $0.11( \pm 0.01)^{\mathrm{a}}$ & $0.24( \pm 0.03)^{\mathrm{b}}$ & $0.12( \pm 0.01)^{\mathrm{a}}$ & \\
\hline
\end{tabular}

Overall means within rows and columns followed by different letters are significantly different $(P<0.05)$ with respect to land use and soil depths.

being returned to the soil system and high rate of oxidation of soil organic matter as a result of continuous cultivation for long period of time without fallowing, loss of organic matter by water erosion, and removal of green materials $[38,39]$. Other studies (e.g. [37, 38]) also reported that the SOC content of the mineral soil was significantly lower in the croplands compared to the grazing and native forest land. Cultivation promotes SOC loss due to exposure of microaggregate organic carbon to microbial decomposition by changing the moisture and temperature regimes [40]. The higher overall SOC content in the protected forest than in farmlands may also be attributed to the higher accumulation of organic matter due to high inputs from root biomass and above ground biomass [38, 40]. The lower content of SOC under open grassland and grazing land may be due to reduced organic matter input because of uncontrolled grazing and browsing [39]. However, according to [41] rating, soil organic carbon content was found to be very low in farmland $\left(18.4 \mathrm{gKg}^{-1}\right)$, and low $\left(26.0-29.7 \mathrm{~g} \mathrm{Kg}^{-1}\right)$ in other land use types, indicating that soils under the protected forest and adjacent land use types are threatened by the continuous animal encroachment, human interference, and intensive agricultural production systems.

3.2.2. Total Nitrogen (TN, $g \mathrm{Kg}^{-1}$ ) and Carbon-Nitrogen Ratio $(\mathrm{C} / \mathrm{N})$. In the study area, the TN did not show any significant variation across all land uses types $(P=0.322)$, soil depth $(P=0.888)$, and the interaction effect $(P=0.533$, Table 4). However, the distribution of total nitrogen content followed a similar pattern to organic carbon distribution and was relatively higher in the protected forest followed by the grazing land than in other land use types. Such result is expected since most soil nitrogen is bound in organic carbon. By contrast, [31] reported a significant difference in TN between the forest and cultivated land due to differences in soil organic matter content, intensities of erosion, and cultivation. Other studies (e.g., [37]) reported that total nitrogen was not significantly varied with land uses. Though not statistically significant, the relatively higher TN in the protected forest and grazing lands than in the open grassland and farmland could be associated with the relatively higher organic carbon which in turn resulted from plant and root 
TABle 4: Summary of two-way ANOVA for SOC, TN, C/N ratio $\mathrm{pH}\left(\mathrm{H}_{2} \mathrm{O}\right), \mathrm{Av}$. P, and Av. K in relation to land use and soil depths.

\begin{tabular}{lcccccccccccccc}
\hline \multirow{2}{*}{ Sources of variations } & \multirow{2}{*}{ df } & \multicolumn{2}{c}{ SOC (\%) } & \multicolumn{2}{c}{ TN (\%) } & \multicolumn{2}{c}{ C/N ratio } & \multicolumn{2}{c}{$\mathrm{pH}$} & \multicolumn{3}{c}{ Av. P } & \multicolumn{2}{c}{ Av. K ${ }^{+}$} \\
& & MS & $P$ & MS & $P$ & MS & $P$ & MS & $P$ & MS & $P$ & MS & $P$ \\
\hline Land use & 3 & 2.22 & 0.001 & 0.02 & 0.322 & 1419 & 0.231 & 0.52 & 0.090 & 16 & 0.093 & 0.061 & $<0.001$ \\
Depth $(D)$ & 1 & 8.81 & $<0.001$ & 0.00 & 0.888 & 1601 & 0.201 & 0.54 & 0.129 & 3.11 & 0.505 & 0.024 & 0.066 \\
LU $* D$ & 3 & 2.64 & $<0.001$ & 0.01 & 0.533 & 1146 & 0.318 & 0.23 & 0.385 & 5.43 & 0.507 & 0.004 & 0.578 \\
Error & 32 & 0.32 & & 0.02 & & 939 & & 0.22 & & 6.85 & & 0.007 \\
\hline
\end{tabular}

biomass as well as residues being returned to the soil system. According to [41] ratings, the TN content in soil of the study area was found to be medium under protected forest and grazing land $\left(2.1 \mathrm{gKg}^{-1} \%\right)$, while being low under open grassland and farmland $\left(1.4 \mathrm{gKg}^{-1}\right)$. The principal cause for lower contents of total nitrogen comes from biomass removal during crop harvest and insufficient replenishment through manure or fertilizers.

Carbon-nitrogen $(\mathrm{C} / \mathrm{N}$ ratio) ratio is an index of nutrient mineralization and immobilization whereby low $\mathrm{C} / \mathrm{N}$ ratio indicates higher rate of mineralization [34]. The $\mathrm{C} / \mathrm{N}$ ratio of the studied soil did not show any significant variation with land use types $(P=0.231)$, soil depth $(P=0.201)$, and their interaction effect $(P=0.318$; Tables 3 and 4). Similarly, [31] reported that $\mathrm{C} / \mathrm{N}$ ratio did not show a significant variation with land uses. The- overall $\mathrm{C} / \mathrm{N}$ ratio was higher in the top surface soil layer than in the layer below. In the study area, the $\mathrm{C} / \mathrm{N}$ ratio was found to be higher (Table 3 ) than the normal range $10: 1$ on average [41] expected in mineral soils. However, other studies (e.g., [30]) reported higher $\mathrm{C} / \mathrm{N}$ ratios indicating that nitrogen is immobilized at higher $\mathrm{C} / \mathrm{N}$ values because of the formation of only slightly biodegradable complexes which are low in nitrogen.

3.2.3. Soil $\mathrm{pH}\left(\mathrm{H}_{2} \mathrm{O}\right)$. Soil $\mathrm{pH}$ did not show any significant variation across land use types or soil depths $(P>0.05$, Table 4). The low soil pH in the lower soil layer than in the top surface soil layer (Table 3) might be due to the presence of relatively higher organic carbon in the top surface soil. According to [41] rating, the overall $\mathrm{pH}$ of the studied soil was found to be moderately acidic.

3.2.4. Available Phosphorus (Av. $P, \mathrm{mgKg}^{-1}$ ). The overall Av. $\mathrm{P}$ did not show any significant difference with land use $(P=$ $0.093)$, soil depth $(P=0.505)$, or their interaction $(P=0.507$; Table 4). The mean Av. P in the top soil layer was significantly higher $\left(5120 \mathrm{mgKg}^{-1}\right)$ in the farmland compared to other land use types $(P<0.05$, Table 3$)$, which may be related to the application of animal manure, compost, and household wastes like ashes for soil fertility improvement. Moreover, farmers have been applying Diammonium phosphate (DAP) fertilizer on their farmland. The lower Av. P content in the protected forest might be related to phosphorus fixation [18]. The overall available phosphorus was lower in the top than in the lower soil layer (Table 3 ).

According to [41] rating, Av. P across all land use was low except in the top soil layer of farmland. The Av. P deficiency in soils of the study area may be due to the inherent low-P status of the parent material and erosion loss. Other studies [32, 35, 42] also reported that the Av. P in most soils of Ethiopia is low due to P- fixation, crop harvest, and erosion by water.

3.2.5. Available Potassium (Av. $K^{+}, \mathrm{cmol}(+) / \mathrm{kg}$ Soil). Available potassium significantly varied with land use types $(P<$ 0.001 , Table 4$)$, higher in soil under the protected-forest (0.26) followed by the farmlands (0.24) than in other land use types (Table 3 ) while no variation was observed with respect to soil depths. Although not significant, the mean available potassium in the top $10 \mathrm{~cm}$ was higher under farmland (0.29) than in the grazing land (0.13) and open grassland (0.12). In the lower soil depth, mean Av. $\mathrm{K}^{+}$did not show any significant difference across all land use types but showed a declining trend with soil depth.

The observed highest concentration of Av. $\mathrm{K}^{+}$under the farmland and protected forest land was attributed to the application of household wastes like ash and a relative pumping of potassium from the subsoil by vegetation in the protected forest land [43]. According to [41] rating, Av. $\mathrm{K}^{+}$concentration in the farmland and protected forest was medium, while being low in the open grass and grazing lands. The lower Av. $\mathrm{K}^{+}$in the open grass land and grazing land could be probably due to soil degradation and losses by leaching as the open grassland and grazing land were denuded of vegetation cover.

3.2.6. Exchangeable Sodium $\left(\mathrm{Na}^{+}\right)$and Potassium $\left(\mathrm{K}^{+}, \mathrm{cmol}\right.$ $(+) / \mathrm{kg}$ Soil). The concentration of exchangeable $\mathrm{Na}^{+}$was the smallest component in the exchange complexes. Generally, the results indicated that exchangeable $\mathrm{K}^{+}$significantly varied with land use types $(P=0.004)$ but not with respect to soil depth $(P=0.138$, Table 6$)$ and the interaction effects $(P=0.419)$, higher in the protected forest land and open grassland (0.08) than in farmland and grazing land (0.04). This result was in line with [29], that the concentration of $\mathrm{Na}^{+}$ was lower in cropland than in the grazing and native forest. Since the concentration of exchangeable $\mathrm{Na}^{+}$did not exceed $1 \mathrm{cmol}(+) / \mathrm{kg}$ soil [41], the soil in the study area would not be regarded as sodic soil. The $\mathrm{pH}$ also showed that the soil is acidic.

There was a significant variation in the overall concentration of exchangeable $\mathrm{K}^{+}$with land use types $(P<0.001)$ and soil depth $(P=0.040)$, higher under farmland (0.62) followed by the protected forest land (0.58) than in the grazing (0.32) and open grasslands (0.30, Table 5) and in the upper than in the lower soil depths. [36] also reported that the concentrations of exchangeable $\mathrm{K}^{+}$was higher in 
TABLE 5: Exchangeable cations ( $\mathrm{cmol}(+) / \mathrm{kg}$ soil), cation exchange capacity $(\mathrm{cmol}(+) / \mathrm{kg}$ soil), and percent base saturation (\%) in relation to land use and soil depths (mean \pm S.E).

\begin{tabular}{|c|c|c|c|c|c|c|}
\hline \multirow{2}{*}{ Variables } & \multirow{2}{*}{ Depth $(\mathrm{cm})$} & \multicolumn{4}{|c|}{ Land use types } & \multirow{2}{*}{ Overall } \\
\hline & & Protected forest & Open grassland & Farmland & Grazing land & \\
\hline \multirow{3}{*}{ Ex. $\mathrm{Na}^{+}$} & $0-10$ & $0.06( \pm 0.003)$ & $0.08( \pm 0.01)$ & $0.04( \pm 0.01)$ & $0.03( \pm 0.01)$ & $0.05( \pm 0.01)^{\mathrm{a}}$ \\
\hline & $10-20$ & $0.10( \pm 0.03)$ & $0.08( \pm 0.01)$ & $0.04( \pm 0.005)$ & $0.05( \pm 0.01)$ & $0.07( \pm 0.01)^{\mathrm{a}}$ \\
\hline & Overall & $0.08( \pm 0.016)^{\mathrm{c}}$ & $0.08( \pm 0.005)^{\mathrm{bc}}$ & $0.04( \pm 0.006)^{\mathrm{ab}}$ & $0.04( \pm 0.005)^{\mathrm{a}}$ & \\
\hline \multirow{3}{*}{ Ex. $\mathrm{K}^{+}$} & $0-10$ & $0.62( \pm 0.02)$ & $0.32( \pm 0.07)$ & $0.68( \pm 0.01)$ & $0.36( \pm 0.07)$ & $0.49( \pm 0.03)^{\mathrm{b}}$ \\
\hline & $10-20$ & $0.54( \pm 0.05)$ & $0.28( \pm 0.07)$ & $0.56( \pm 0.02)$ & $0.28( \pm 0.06)$ & $0.42( \pm 0.03)^{\mathrm{a}}$ \\
\hline & Overall & $0.58( \pm 0.03)^{\mathrm{b}}$ & $0.30( \pm 0.05)^{\mathrm{a}}$ & $0.62( \pm 0.02)^{\mathrm{b}}$ & $0.32( \pm 0.05)^{\mathrm{a}}$ & \\
\hline \multirow{3}{*}{ Ex. $\mathrm{Ca}^{2+}$} & $0-10$ & $4.33( \pm 0.07)$ & $2.69( \pm 0.60)$ & $4.17( \pm 0.05)$ & $3.32( \pm 0.12)$ & $3.63( \pm 0.20)^{b}$ \\
\hline & $10-20$ & $2.99( \pm 0.54)$ & $2.38( \pm 0.68)$ & $3.78( \pm 0.16)$ & $2.68( \pm 0.40)$ & $2.96( \pm 0.20)^{\mathrm{a}}$ \\
\hline & Overall & $3.66( \pm 0.34)$ & $2.54( \pm 0.43)^{\mathrm{a}}$ & $3.98( \pm 0.10)^{\mathrm{b}}$ & $3.00( \pm 0.23)^{\mathrm{ab}}$ & \\
\hline \multirow{3}{*}{ Ex. $\mathrm{Mg}^{2+}$} & $0-10$ & $0.75( \pm 0.005)$ & $0.61( \pm 0.07)$ & $0.73( \pm 0.002)$ & $0.76( \pm 0.04)$ & $0.71( \pm 0.02)^{\mathrm{a}}$ \\
\hline & $10-20$ & $0.72( \pm 0.01)$ & $0.49( \pm 0.11)$ & $0.72( \pm 0.005)$ & $0.70( \pm 0.01)$ & $0.66( \pm 0.02)^{\mathrm{a}}$ \\
\hline & Overall & $0.73( \pm 0.01)^{\mathrm{b}}$ & $0.55( \pm 0.06)^{\mathrm{a}}$ & $0.73( \pm 0.003)^{\mathrm{b}}$ & $0.73( \pm 0.02)^{\mathrm{b}}$ & \\
\hline \multirow{3}{*}{ CEC } & $0-10$ & $18.20( \pm 4.89)$ & $10.44( \pm 2.06)$ & $22.52( \pm 2.24)$ & $15.52( \pm 2.69)$ & $16.67( \pm 1.60)^{\mathrm{a}}$ \\
\hline & $10-20$ & $18.00( \pm 3.59)$ & $16.40( \pm 1.85)$ & $18.84( \pm 4.38)$ & $12.44( \pm 2.52)$ & $16.42( \pm 1.60)^{\mathrm{a}}$ \\
\hline & Overall & $18.10( \pm 2.86)^{\mathrm{a}}$ & $13.42( \pm 1.64)^{\mathrm{a}}$ & $20.68( \pm 2.40)^{\mathrm{a}}$ & $13.98( \pm 1.81)^{\mathrm{a}}$ & \\
\hline \multirow{3}{*}{ PBS } & $0-10$ & $39.95( \pm 8.22)$ & $39.25( \pm 9.42)$ & $25.90( \pm 2.28)$ & $34.32( \pm 8.39)$ & $34.86( \pm 4.35)^{\mathrm{a}}$ \\
\hline & $10-20$ & $27.10( \pm 5.50)$ & $21.09( \pm 5.74)$ & $40.92( \pm 16.0)$ & $34.54( \pm 7.88)$ & $30.86( \pm 4.35)^{\mathrm{a}}$ \\
\hline & Overall & $33.53( \pm 5.13)^{\mathrm{a}}$ & $30.17( \pm 6.02)^{\mathrm{a}}$ & $33.30( \pm 8.02)^{\mathrm{a}}$ & $34.43( \pm 5.43)^{\mathrm{a}}$ & \\
\hline
\end{tabular}

Overall means within rows and columns followed by different letters are significantly different $(P<0.05)$ with respect to land use types and soil depths.

TABLE 6: Summary of ANOVA for exchangeable cations, CEC, and PBS in relation to land use and soil depths.

\begin{tabular}{|c|c|c|c|c|c|c|c|c|c|c|c|c|c|}
\hline \multirow{2}{*}{ Sources of variations } & \multirow{2}{*}{ df } & \multicolumn{2}{|c|}{ Ex. $\mathrm{Na}^{+}$} & \multicolumn{2}{|c|}{ Ex. $\mathrm{K}^{+}$} & \multicolumn{2}{|c|}{ Ex. $\mathrm{Ca}^{2+}$} & \multicolumn{2}{|c|}{ Ex. $\mathrm{Mg}^{2+}$} & \multicolumn{2}{|c|}{ CEC } & \multicolumn{2}{|c|}{ PBS } \\
\hline & & MS & $P$ & MS & $P$ & MS & $P$ & MS & $P$ & MS & $P$ & MS & $P$ \\
\hline Land use & 3 & 0.005 & 0.004 & 0.29 & $<0.001$ & 4.205 & 0.005 & 0.084 & 0.001 & 119.54 & 0.093 & 34.83 & 0.964 \\
\hline Depth $(D)$ & 1 & 0.002 & 0.138 & 0.06 & 0.040 & 4.526 & 0.026 & 0.03 & 0.119 & 0.625 & 0.913 & 155.4 & 0.521 \\
\hline $\mathrm{LU} * D$ & 3 & 0.001 & 0.419 & 0.013 & 0.885 & 0.559 & 0.573 & 0.007 & 0.647 & 48.62 & 0.430 & 548.4 & 0.253 \\
\hline Error & 32 & 0.001 & & 0.003 & & 0.826 & & 0.012 & & 51.39 & & 383.2 & \\
\hline
\end{tabular}

soil under the farmlands compared to the adjacent natural forest. The higher concentration of exchangeable $\mathrm{K}^{+}$in the top surface layer than in the lower soil layer (Table 5) suggests that vegetation pumps bases such as $\mathrm{K}^{+}, \mathrm{Ca}^{2+}$ and $\mathrm{Mg}^{2+}$ from the subsoil to the topsoil [29]. According to [41] ratings, the studied soil under different land use types has medium to high concentration of exchangeable $\mathrm{K}^{+}(\geq 0.6 \mathrm{cmol} / \mathrm{kg}$ soil), and thus, response to $\mathrm{K}$ fertilizer is unlikely.

3.2.7. Exchangeable Calcium $\left(\mathrm{Ca}^{2+}\right)$ and Magnesium $\left(\mathrm{Mg}^{2+}\right.$, cmol (+)/ $\mathrm{kg}$ Soil). The concentration of exchangeable $\mathrm{Ca}^{2+}$ significantly varied with land use types $(P=0.005)$ and soil depth $(P=0.026)$, higher in the farmland (3.98) and protected forest land (3.66) than in other land use types (Table 5). The low exchangeable $\mathrm{Ca}^{2+}$ in the grazing land and open grassland was probably due to the removal of vegetation cover as a result of human and livestock interference. In the top surface soil layer, the concentration of exchangeable $\mathrm{Ca}^{2+}$ was higher in the protected forest (4.33) and farmlands (4.17) than in open grassland (2.69, Table 5). The significantly higher concentration of exchangeable $\mathrm{Ca}^{2+}$ in the top than in the lower soil layer was probably due to the application of household wastes (ash) in the fields because ash is a good source of $\mathrm{Ca}^{2+}, \mathrm{K}^{+}, \mathrm{P}$, and $\mathrm{Mg}^{2+}$ [44] and pumping of bases from the subsoil by the vegetation and returning them into the topsoil [29]. A critical concentration of $0.2 \mathrm{cmol} / \mathrm{kg}$ soil is required for tropical soils [41] and this would indicate that exchangeable $\mathrm{Ca}^{2+}$ is not a limiting in the soil of study area. Concentration of exchangeable $\mathrm{Mg}^{2+}$ showed a significant variation with land use types $(P=0.001$, Table 6$)$ while no variation was observed with respect to soil depth $(P=0.119)$. Exchangeable $\mathrm{Mg}^{2+}$ was lower under open grassland than other land use types (Table 5). Generally, the concentration of exchangeable $\mathrm{Mg}^{2+}$ was higher (sufficient) than the critical level of $0.5 \mathrm{cmol} / \mathrm{kg}$ soil as suggested by [41]; a concentration less than this value would require an application of magnesium limestone accordingly.

3.2.8. Cation Exchange Capacity (CEC, $\mathrm{cmol}(+) / \mathrm{kg}$ Soil) and Percent Base Saturation (PBS, \%). CEC did not show any 
significant variation across all land use types $(P=0.093$, Table 5), soil depth $(P=0.913)$, or the interaction effects $(P=0.430$; Table 6$)$. Though not statistically significant, CEC was relatively higher in the farmland (20.68) followed by protected forest (18.10), than in other land use types (Table 5). According to [41] ratings, the concentration of CEC was found to be low both in the open grassland and grazing land, indicating the low level fertility status of the soil under the two land use types [33]. The soil fertility level both under farmland (20.68) and protected forest (18.10) was medium due to the application of animal manure, house hold wastes, and residues which are sources of $\mathrm{Ca}^{2+}, \mathrm{K}^{+}, \mathrm{P}^{2} \mathrm{Mg}^{2+}$ [44]; and due to the relatively higher content of organic matter, respectively.

Percent base saturation (PBS) is frequently used as an indication of the fertility status of soil [30] The PBS did not significantly vary with land use types $(P=0.964)$, soil depth $(P=0.521)$, and the interaction effects $(P=0.253$, Table 6$)$. However, the PBS was relatively higher under grazing land $(34.43 \%)$ than other land use types and in the top than in the lower soil layer (Table 5).

\section{Conclusions}

Variations in soil quality indicators with respect to land use and soil depths were investigated in the Abo-Wonsho area. Soil textural fractions varied with land use, while silt, clay, and bulk density differed with soil depths. Among soil chemical quality indicators SOC, available $\mathrm{K}^{+}$and exchangeable bases varied significantly with land use. Human mismanagement land resources, excessive livestock grazing in the protected forest areas, and intensive agricultural production in adjacent farmland have caused deterioration in soil quality indicators. This documents that the cultural forest management system has not protected soil quality.

Though Abo-Wonsho was believed to be protected for the last 21 generations, there has been no improvement in the soil quality when compared to the adjacent land use. Therefore, in order to improve soil quality, reverse deterioration, and maintain long-term productivity of the agricultural land the following practices are suggested: (1) integrating existing cultural management practices with appropriate technologies such as reforestation, excluding the forest from human and livestock interference and controlling soil erosion in the area; (2) strengthening and expanding existing fertility management practices such as organic fertilizer (household wastes, manure, composts) to sustain agricultural production; (3) providing technical support to the concerned cultural leaders is crucial. Finally, Abo-Wonsho and its surrounding areas are lacking scientific studies on forest resources like species composition, structure, diversity, and management. Identifying and characterizing soil types and distribution are also among the critical research gaps that need to be filled for this area.

\section{Acknowledgments}

The authors greatly acknowledge the cooperation and support of the farmers in the Abo-Wonso area. They are grateful for the financial support for the research by the Christensen fund through Center for Environment and Society at HU-CA. The anonymous reviewers' comments are greatly acknowledged.

\section{References}

[1] D. L. Karlen, M. J. Mausbach, J. W. Doran, R. G. Cline, R. F. Harris, and G. E. Schuman, "Soil quality: a concept, definition, and framework for evaluation," Soil Science Society of America Journal, vol. 61, no. 1, pp. 4-10, 1997.

[2] A. R. Dexter, "Soil physical quality—part I. Theory, effects of soil texture, density, and organic matter, and effects on root growth," Geoderma, vol. 120, no. 3-4, pp. 201-214, 2004.

[3] M. J. Singh Dr. and K. L. Khera, "Physical indicators of soil quality in relation to soil erodibility under different land uses," Arid Land Research and Management, vol. 23, no. 2, pp. 152-167, 2009.

[4] F. Khormali, M. Ajami, S. Ayoubi, C. Srinivasarao, and S. P. Wani, "Role of deforestation and hillslope position on soil quality attributes of loess-derived soils in Golestan province, Iran," Agriculture, Ecosystems and Environment, vol. 134, no. 3-4, pp. 178-189, 2009.

[5] P. Vityakon, "Degradation and restoration of sandy soils under different agricultural land uses in northeast Thailand: a review," Land Degradation and Development, vol. 18, no. 5, pp. 567-577, 2007.

[6] T. Yüksek, O. Kurdoğlu, and F. Yüksek, “The effects of land use changes and management types on surface soil properties in Kafkasör protected area in Artvin, Turkey," Land Degradation and Development, vol. 21, no. 6, pp. 582-590, 2010.

[7] E. Ozgoz, H. Gunal, N. Acir, F. Gokmen, M. Birol, and M. Budak, "Soil quality and spatial variability assessment of land use effects in a typic haplustoll," Land Degradation and Development, 2011.

[8] F. García-Orenes, A. Roldán, J. Mataix-Solera et al., "Soil structural stability and erosion rates influenced by agricultural management practices in a semi-arid Mediterranean agroecosystem," Soil Use and Management, vol. 28, no. 4, pp. 571-579, 2012.

[9] F. García-Orenes, C. Guerrero, A. Roldán et al., "Soil microbial biomass and activity under different agricultural management systems in a semiarid Mediterranean agroecosystem," Soil and Tillage Research, vol. 109, no. 2, pp. 110-115, 2010.

[10] F. García-Orenes, A. Cerdà, J. Mataix-Solera et al., "Effects of agricultural management on surface soil properties and soilwater losses in eastern Spain," Soil and Tillage Research, vol. 106, no. 1, pp. 117-123, 2009.

[11] E. Barrios and M. T. Trejo, "Implications of local soil knowledge for integrated soil management in Latin America," Geoderma, vol. 111, no. 3-4, pp. 217-231, 2003.

[12] World Bank, Indigenous Knowledge: Local Pathways to Global Development, Knowledge and Learning Center, Africa Region: World Bank, 2004.

[13] R. R. Pawluk, J. A. Sandor, and J. A. Tabor, "The role of indigenous soil knowledge in agricultural development," Journal of Soil \& Water Conservation, vol. 47, no. 4, pp. 298-302, 1992.

[14] B. Tesfaye, Understanding Farmers: Explaining Soil and Water Conservation in Konso, Wolaita and Wollo [Ph.D. thesis], Wageningen University, Wageningen, The Netherlands, 2003. 
[15] H. Solomon and K. Yoshinobu, "Traditional Irrigation management in Betmera-Hiwane, Ethiopia: the main peculiarities for persistence of irrigation practices," Journal of Mountain Science, vol. 2, pp. 139-146, 2006.

[16] M. Alemayehu, F. Yohannes, and P. Dubale, "Effect of indigenous stone bunding (KAB) on crop yield at Mesobit-Gedeba, North Shoa, Ethiopia," Land Degradation and Development, vol. 17, no. 1, pp. 45-54, 2006.

[17] W. Alemayehu, Ethiopian church forests: opportunities and challenges for restoration [Ph.D. thesis], Wageningen University, Wageningen, The Netherlands, 2007.

[18] F. Yimer, S. Ledin, and A. Abdelkadir, "Soil property variations in relation to topographic aspect and vegetation community in the south-eastern highlands of Ethiopia," Forest Ecology and Management, vol. 232, no. 1-3, pp. 90-99, 2006.

[19] F. Bastida, A. Zsolnay, T. Hernández, and C. García, "Past, present and future of soil quality indices: a biological perspective," Geoderma, vol. 147, no. 3-4, pp. 159-171, 2008.

[20] Ethiopian National Meteorology Agency (ENMA), Meteorological Data, Addis Ababa, Ethiopia, 2008.

[21] Sidama Zone Finance and Economic Development sector (SZFEDS), "Socio-economic study," Southern Nations Nationalities People Regional state, Ethiopia, 2007.

[22] J. R. Blake and K. H. Hartge, "Bulk Density," in Methods in Soil Analysis-Part 1. Physical and Mineralogical Methods, A. Klute, Ed., pp. 363-376, American Society of Agronomy, Madison, Wis, USA, 2nd edition, 1986.

[23] C. A. Black, D. D. Evans, J. L. White, L. E. Ensminger, and F. E. Clark, Methods of Soil Analysis-Part 1. Physical and Mineralogical Properties Including Statistics of Measurement and Sampling, American Society of Agronomy, Madison, Wis, USA, 1965.

[24] M. Schnitzer, "Total carbon, organic matter and carbon," in Methods of Soil Analysis-Part 2, Agronomy Monograph, A. L. Page, R. H. Miller, and D. R. Keeney, Eds., vol. 9, pp. 539577, American Society of Agronomy, Madison, Wis, USA, 2nd edition, 1982.

[25] J. M. Bremner and C. S. Mulvaney, "Nitrogen-Total," in Methods of Soil Analysis, A. L. Page, R. H. Miller, and D. R. Keeney, Eds., vol. 2, pp. 595-624, American Society of Agronomy, Madison, Wis, USA, 1982.

[26] S. R. Olsen and L. A. Dean, "Phosphorous," in Methods of Soil Analysis-Part 2: Chemical and Microbiological Properties, C. A. Black, Ed., vol. 9, pp. 1035-1049, American Society of Agronomy, Madison, Wis, USA, 1965.

[27] B. J. J. Jones, Laboratory Guide For Conducting Soil Tests and Plant Analysis, CRC press, LLC, 2001.

[28] H. D. Chapman, "Cation exchange capacity," in Methods of Soil Analysis, C. A. Black, Ed., pp. 891-901, American Society of Agronomy, Madison, Wis, USA, 1965.

[29] F. Yimer, S. Ledin, and A. Abdelkadir, "Concentrations of exchangeable bases and cation exchange capacity in soils of cropland, grazing and forest in the Bale Mountains, Ethiopia," Forest Ecology and Management, vol. 256, no. 6, pp. 1298-1302, 2008.

[30] W. Chesworth, Encyclopedia of Soil Science, Springer, Dordrecht, The Netherlands, 2008.

[31] S. Khresat, J. Al-Bakri, and R. Al-Tahnan, "Impacts of land use/cover change on soil properties in the Mediterranean region of northwestern Jordan," Land Degradation and Development, vol. 19, no. 4, pp. 397-407, 2008.
[32] M. Sintayehu, Land Use Dynamics and its Impact on Selected Physicochemical Properties of Soils in Yabello Woreda of Borana Lowlands, Southern Ethiopia [M.S. thesis], Haromaya University, Haromaya, Ethiopia, 2006.

[33] H. D. Foth, Fundamentals of Soil Science, John Wiley and Sons, New York, NY, USA, 8th edition, 1990.

[34] N. C. Brady and R. R. Weil, The Nature and Properties of Soils, Prentice-Hall, Upper Saddle River, NJ, USA, 13th edition, 2002.

[35] T. Gebeyaw, Soil Fertility Status as Influenced by Different Land Uses in Maybar Areas of South Wello Zone, Ethiopia [M.S. thesis], Haromaya University, Haromaya, Ethiopia, 2006.

[36] M. Lemenih, E. Karltun, and M. Olsson, "Assessing soil chemical and physical property responses to deforestation and subsequent cultivation in smallholders farming system in Ethiopia," Agriculture, Ecosystems and Environment, vol. 105, no. 1-2, pp. 373-386, 2005.

[37] A. Moges and N. M. Holden, "Soil fertility in relation to slope position and agricultural land use: a case study of umbulo catchment in Southern Ethiopia," Environmental Management, vol. 42, no. 5, pp. 753-763, 2008.

[38] F. Yimer, S. Ledin, and A. Abdelkadir, "Changes in soil organic carbon and total nitrogen contents in three adjacent land use types in the Bale Mountains, south-eastern highlands of Ethiopia," Forest Ecology and Management, vol. 242, no. 2-3, pp. 337-342, 2007.

[39] G. Girmay, B. R. Singh, H. Mitiku, T. Borresen, and R. Lal, "Carbon stocks in Ethiopian soils in relation to land use and soil management," Land Degradation and Development, vol. 19, no. 4, pp. 351-367, 2008.

[40] D. C. Reicosky and F. Forcella, "Cover crop and soil quality interactions in agroecosystems," Journal of Soil and Water Conservation, vol. 53, no. 3, pp. 224-229, 1998.

[41] J. R. Landon, Ed., Booker Tropical Soil Manual: A Handbook for Soil Survey and Agricultural Land Evaluation in the Tropics and Subtropics, Longman Scientific and Technical, New York, NY, USA, 1991.

[42] N. Wakene and G. Heluf, "Forms of phosphorus and status of available micronutrients under different land-use systems of alfisols in Bako Area of Ethiopia," Ethiopian Journal of Natural Resources, vol. 5, pp. 17-37, 2003.

[43] H. L. Bohn, B. L. Mcneal, H. L. O'connor, B. L. Mcneal, and G. A. O'connor, Soil Chemistry, John Wiley \& Sons, New York, Ny, USA, 3rd edition, 2001.

[44] J. C. Voundi Nkana, A. Demeyer, and M. G. Verloo, "Chemical effects of wood ash on plant growth in tropical acid soils," Bioresource Technology, vol. 63, no. 3, pp. 251-260, 1998. 

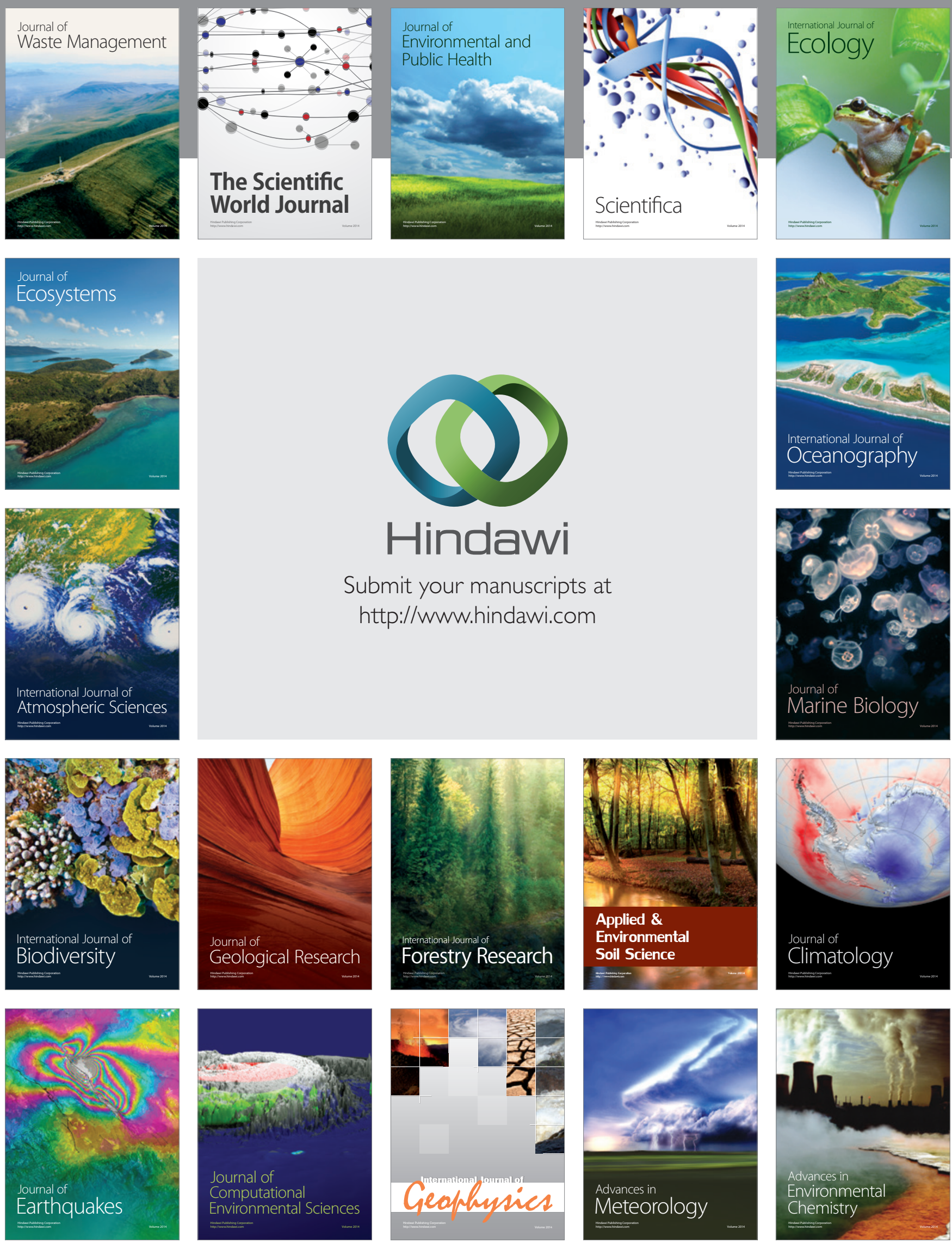